\title{
EnGAGE: Integrating Engineering and Civic Engagement
}

\section{Dr. Alandra Kahl, Pennsylvania State University, Greater Allegheny}

Dr. Alandra Kahl currently teaches engineering design and sustainable systems at The Pennsylvania State University, Greater Allegheny campus. She received her doctorate in environmental engineering from the University of Arizona in 2013, where her dissertation focused on the fate and transport of contaminants of emerging concern in an arid region. Dr. Kahl's research interests include engineering of sustainable systems, treatment of emerging contaminants via natural systems and engineering education. She is the author of several technical papers and conference proceedings centered on environmental engineering. Her professional affiliations include the American Society of Civil Engineers, the American Chemical Society, and the American Society for Engineering Education. 


\section{EnGAGE: Integrating Engineering and Civic Engagement}

Abstract:

A recent focus in engineering education has been the integration of project based learning and interdisciplinary coursework. Students are more apt to continue with the discipline if we engage them early and in innovative ways. This paper details the inception and construction of EnGAGE, an interdisciplinary collaboration between the Engineering Design course, and the Civic and Community Engagement course. EnGAGE is a community garden/gateway that will serve the region as well as provide educational opportunities for our students in both civic engagement and engineering.

In fall 2014, McKeesport, Pennsylvania was identified as a site for community renewal by a local non-profit, GTECH Strategies. Two faculty from the Penn State Greater Allegheny campus, located in McKeesport, were invited to participate as project ambassadors in the effort. Students had previously conceived the idea of a community garden during earlier interdisciplinary efforts. The EnGAGE project was used as an innovative way to promote collaboration between the two classes while achieving traditional course goals in each. Students were involved in all aspects of the project, including site assessment, design, planning and will be an integral part of construction of the garden. Participants completed short pre and post surveys during various phases of the project, and will be resurveyed at the project conclusion as well as asked to write reflections on their to gain qualitative and quantitative data regarding project success.

\section{Introduction:}

Entry level engineering courses are beginning to emphasize production of a more well-rounded engineer through service and community involvement. Interest in outside of the classroom activity that serves others has also grown rapidly over the last few years. Examples of volunteer organizations that serve this population include Engineers Without Borders and Engineers for a Sustainable World, both of whose memberships number in the thousands. Other common campus community partners include Habitat for Humanity and local soup kitchens which engage all of the student community. The EPICS program headed up by Purdue is one of the best known projects bringing community service into engineering ${ }^{2}$.

This paper details the initial project work and reclamation of a vacant space near the entryway of campus between the students of engineering design and civic and community engagement classes, and a local nonprofit, GTECH Strategies. Students in engineering are required to take design as a major course, but civic and community engagement is an elective course. Student participation in the GTECH Strategies initiative was entirely voluntary. Our student pool is primarily first year, first generation college students. As it is a small campus, the total number of students involved in the project is not large $(\sim 40)$, and students are primarily freshman and sophomore level. The area, which used to be an industrial hub, has experienced significant economic hardship due to the decline of the steel industry. Exodus of industry from the area has resulted in many parcels of vacant land in the area. The plots of vacant land are often eyesores, exacerbating blight and decline in the neighborhoods where they are present. McKeesport has 
over 2,000 plots of vacant land. This project is unique in that it is the first time the nonprofit has worked outside of the nearby city of Pittsburgh for a community partnership, as well as with a small campus population rather than a large university pool. The partnership is novel as it is student driven in a working class community where academics are not traditionally prized. Many of those involved have never participated in a service learning project and have little experience in volunteer work in the community.

\section{Background:}

Service learning refers to the method of teaching in which classroom instruction is integrated with community service ${ }^{1}$. It exists to allow students to immediate utilize skills learned in the classroom to enhance their communities through civic engagement and community development. The Learn and Serve America program administered by the United States government as an outgrowth of the National and Community Service Act of 1990 was one of the earliest instances of the service learning movement in the classroom ${ }^{1}$. It later evolved into what is known today as AmeriCorps. As service learning is experiential, students are actively engaged during the learning process through community involvement. Additional key components of service learning are collaboration, reflection and evaluation. Students are encouraged to seek active meaning in their work to gain the most from the service learning experience.

Philosophies of service learning originate with the idea of progressivism in education, championed by John Dewey, and pragmatism from William James. These philosophies are a central theme of the movement. Progressivism as defined by Dewey focuses on the actions of learning by doing ${ }^{3}$. Dewey observed that students retain information better when they learn through a cycle of action and reflection. Progressivism in education characterized by providing students with quality experiences which reinforce concepts learned in the classroom ${ }^{3}$. William James' philosophy of pragmatism is also prominent in service learning. In writings, James characterized a pragmatic approach as connection between ideas with actions ${ }^{7}$. William James argued that knowledge was essentially useless unless it could be directly applied ${ }^{7}$. The roots of service learning come from these ideas of 'learning while doing.'

There are many benefits to service learning, as noted in the text "Where's the Learning in Service Learning" by Janet Eyler and Dwight Giles. Eyler and Giles cite as benefits the development of problem solving skills, interpersonal development, cognitive advancement, and enhanced world views ${ }^{5}$. The role of reflection is also noted to be a critical component in service learning. This period of evaluation of ones learning, goals and experiences is important to helping students realize the connections between theory and practice ${ }^{5}$.

Experiential learning like service learning is an increasingly important element of the new engineering curriculum. Educators have devoted more time to producing an engineer that has not only the required skills, but also societal and global awareness. Service learning projects connect traditional classroom teaching with real world needs on a local or even global scale. Project based learning stimulates the process of collaborative problem solving, a skill that has been identified as important for the future engineer. Additionally, student interest in service learning has created institutional momentum for integration with traditional subjects. There are other benefits to service learning; one can cite positive impacts on interest, motivation, student 
satisfaction, personal success, desire, faculty-student interaction, and retention of students who participate in service learning projects ${ }^{8,9,11}$. Service learning has also been shown to increase retention of women and underrepresented minorities in engineering ${ }^{10,12,13}$.

Service learning is the core guiding feature of this project, which aims to connect the local community with the Penn State Greater Allegheny campus through conception and construction of a gathering space located at the entrance to campus. It should be noted that the college campus is located on the edge of a small neighborhood and shopping district, within walking distance of the local high school. The multiuse nature of the property makes it ideal for location of a community space, particularly one aimed at youth as we envision. The campus serves many underrepresented groups in engineering; a large percentage of students are minority and/or first in family college students. It should also be noted that the campus space is adjacent to a local park; so many students also cited potential for partnerships with the existing amenities.

Community Partnership:

The GTECH Strategies partnership is a nonprofit partnership funded by the Heinz foundation that selects ambassadors to improve vacant plots in their neighborhoods. Organizations apply to be partners with the nonprofit who in turn provides a stipend for a community projects and training on site selection, design, and project management. Penn State Greater Allegheny was chosen as an ambassador team for the 2014-2015 grant cycle. Following a seminar given by GTECH Strategies about the project, students were surveyed regarding their interest in the project and the perceived impact on the community of rehabilitation of a site in the local area. A site was chosen from a pool of vacant land owned by the city.

Site design was based on a student survey in partnership with landscape architects from GTECH Strategies. For the students a common theme was recreation and gathering space. During stakeholder engagement discussions with GTECH Strategies and the student group, it was chosen to build a community garden/gateway for students to utilize on campus. Elements of the space include a chalkboard for expression, and public art installations. GTECH Strategies suggested the inclusion of public art as a way for the community to create a presence as stakeholders in the community.

Design and construction:

Students in partnership with GTECH Strategies will construct the space, using the $\$ 3000$ budget provided by GTECH Strategies. Materials are primarily salvaged from construction debris provided by a local company, and donated items. Examples of creative use of salvage items include tractor tires which will provide seating and donated crushed stone for a path to the space. Conceptualization of the space first occurred independently. Both engineering design and civic and community engagement were scaffolded into the tenets of community development and design for the community through introductory lectures and guest speakers. In particular, they first learned the principles of good design and agitation for change from Dym and Little, and Robert Gass's text "What is Transformation? And How it Advances Social Change" 4,6. Visiting speakers from both GTECH Strategies and local planners Environmental Design also lectured about the elements of design for the community. 
Engineering design students used the seven step process to build design wheels (shown in Figure 1) approaching the problem of design of a community space as an independent exercise.

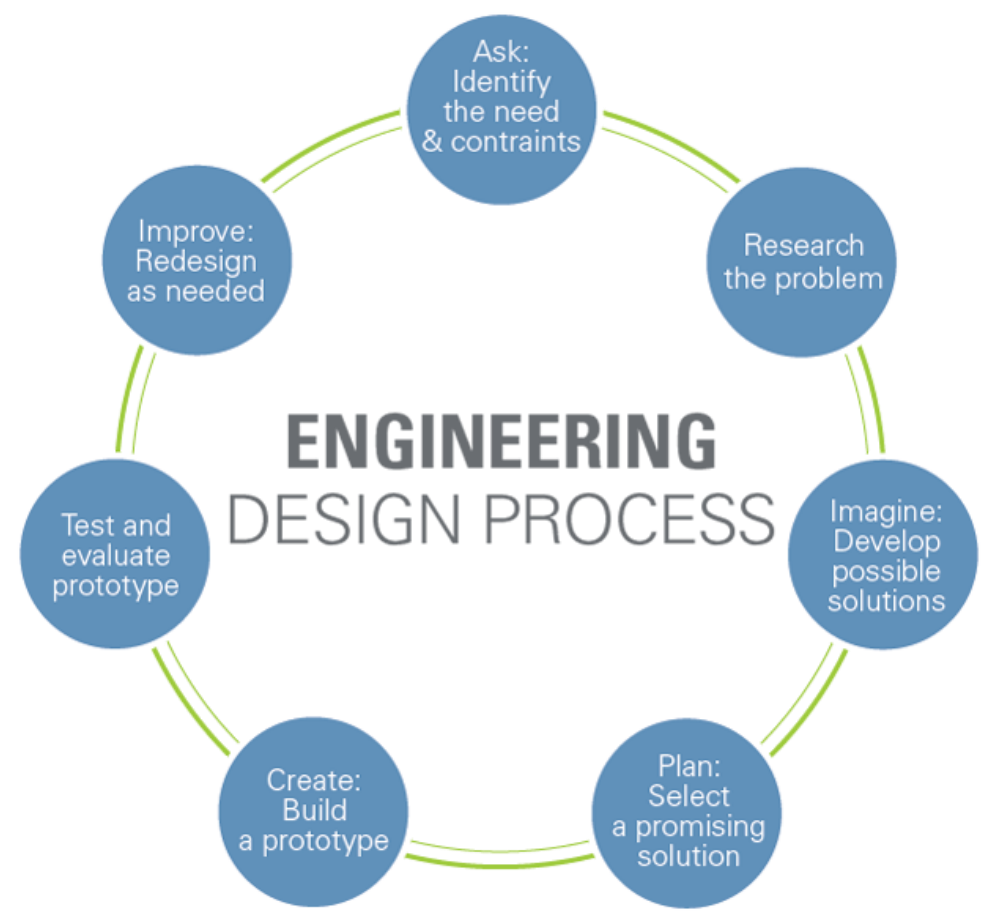

Figure 1: Engineering design process wheel ${ }^{14}$.

The design wheels were then presented to the class and discussed. The most common response to the exercise was a recreation based space (basketball court, soccer field, etc.). Civic and community engagement students used the Gass wheel of transformation as a beginning independent exercise ${ }^{6}$. Students identified the impetus for change, stakeholders and those areas which would be most amenable to new multiuse space. In particular, students identified elements which they felt should be included in the new area. Students discussed their design as a class, critiquing each other's work. Students also evaluated community spaces on other campuses in the Penn State Greater Allegheny system. Of particular interest was a joint pollinator garden and fire pit on a neighboring campus. This space had been constructed originally as a showcase project and grown to be an engaging space with student participation.

Following independent activities, the two classes met to talk about each other's perspectives on the project, and present their ideas. The engineering class was largely engaged with the feasibility of design, while the civic and community engagement class was focused on usage of the space. Both classes benefited from constructive criticism and focused feedback about their design. The civic and community engagement class also collaborated on a survey in conjunction with the city of McKeesport. This survey was distributed to faculty, staff and students as well as the community. The aim of the survey was engage stakeholders from all interested groups in planning for future spaces, including the area discussed herein. 
The Penn State Greater Allegheny administration, as a stakeholder, also offered critique on the design. Due to the shape of the parcel, it was suggested that a "gateway garden" or an exhibition of public art would be a preferred usage of the space. It was also suggested that maintenance and upkeep would be a significant concern for the campus, as most student tenure is two years of residency rather than the traditional four years for most colleges. Penn State Greater Allegheny also provided a list of approved plants for vegetation; these varieties were selected by facilities for hardiness, adaptation to the local climate and upkeep. It was also noted that leveraging additional funds for the project would be contingent on meeting these guidelines. Upon discussion, it was also discovered that partnership linkages for the project could be made with other faculty. Interdisciplinary efforts are highly encouraged, as they bring potential for diverse community engagement and broad stakeholder buy-in. The first project was a vision for a diversity garden, showcasing the multi-cultural nature of the campus, driven by a faculty member in the social sciences. Their vision was a collaborative seating space that could be used for discussion. We sought to build on this idea by suggesting a chalkboard wall where writing prompts could be displayed and student responses recorded. The second project was a composting initiative in the planning stages for a class focused on sustainability lead by a professor also in engineering. The composting idea was also embraced, as the compost generated by the project could be used to fertilize plantings in the engagement space.

Methodology:

Our effort for this project consists of two main goals:

Goal 1: To encourage sustainable design for community improvement in engineering design and civic and community engagement.

Goal 2: To promote interdisciplinary collaboration, self-efficacy and leadership while embracing community identity.

Each of these goals are in line with new ABET criteria focused on educating the "whole engineer." To measure our progress toward these goals, we have begun to capture student attitudes via surveys and plan an additional survey and a limited number of interviews at the project conclusion. Survey responses are measured via a Likert scale of 1-5 (strongly disagree to strongly agree) and written comments to a series of statements reflecting on the project. Figure 1 shows an example of a portion of the survey and responses. Participants are gathered from both engineering design and civic and community engagement students. For this project, our goals for student learning primarily encompass Goals 1 and 2. Specifically, we hope to provide students with a collaborative experience across the disciplines of community engagement and engineering by engaging them in traditional course content through the innovative platform of EnGAGE. Typical goals for these courses include exposure and usage of the engineering design process (Engineering Design), and engagement in community based learning (Civic and Community Engagement). We are fortunate in that the goals expressed above are also reflected in the goals embraced by the community partner of improvement, engagement and collaboration within the community. We have begun to assess our progress toward meeting these goals by surveying students involved in the project periodically. At the conclusion of the project we will compile the data generated along with student reflections to determine if our goals have been achieved. 
Assessment of those involved with the project is planned to occur both before and after construction. Prior to construction, students were asked questions regarding the interaction of the campus and the community, the impact of student/community partnerships on the community, as well as given additional space to brainstorm ideas for an engaging space.

\begin{tabular}{|c|c|c|c|c|c|c|c|c|}
\hline & $\nabla$ & $\begin{array}{l}\text { Strongly } \\
\text { Disagree }\end{array}$ & Disagree $\vee$ & $\begin{array}{l}\text { Neither } \\
\text { Disagree } \\
\text { Nor } \\
\text { Agree }\end{array}$ & Agree & $\begin{array}{l}\text { Strongly } \\
\text { Agree }\end{array}$ & Total $\sim$ & $\begin{array}{l}\text { Weighted } \\
\text { Average }\end{array}$ \\
\hline$\nabla$ & $\begin{array}{l}\text { The GTECH } \\
\text { project is a } \\
\text { good } \\
\text { partnership }\end{array}$ & $\begin{array}{r}\mathbf{5 . 8 8 \%} \\
1\end{array}$ & $\begin{array}{r}0.00 \% \\
0\end{array}$ & $\begin{array}{r}\mathbf{5 . 8 8 \%} \\
1\end{array}$ & $\begin{array}{r}41.18 \% \\
7\end{array}$ & $\begin{array}{r}47.06 \% \\
8\end{array}$ & 17 & 4.24 \\
\hline$\nabla$ & $\begin{array}{l}\text { The GTECH } \\
\text { nonprofit is } \\
\text { a strong } \\
\text { force in the } \\
\text { community }\end{array}$ & $\begin{array}{r}5.88 \% \\
1\end{array}$ & $\begin{array}{r}0.00 \% \\
0\end{array}$ & $\begin{array}{r}\mathbf{5 . 8 8 \%} \\
1\end{array}$ & $\begin{array}{r}52.94 \% \\
9\end{array}$ & $\begin{array}{r}35.29 \% \\
6\end{array}$ & 17 & 4.12 \\
\hline$\nabla$ & $\begin{array}{l}\text { The GTECH } \\
\text { project has } \\
\text { potential for } \\
\text { community } \\
\text { revitalization }\end{array}$ & $\begin{array}{r}\mathbf{5 . 8 8 \%} \\
1\end{array}$ & $\begin{array}{r}0.00 \% \\
0\end{array}$ & $\begin{array}{r}\mathbf{5 . 8 8 \%} \\
1\end{array}$ & $\begin{array}{r}35.29 \% \\
6\end{array}$ & $\begin{array}{r}52.94 \% \\
9\end{array}$ & 17 & 4.29 \\
\hline
\end{tabular}

Figure 2: Example survey responses.

An important element of the dataset (shown in Figure 2) was that students responded that they felt that they were a part of community and engaged with the local area, even prior to the construction of the project. Following construction (in the coming spring and summer), students will again be asked to participate in the survey. Students were engaged in small ways; through volunteering with Habitat for Humanity and THON, a large annual fundraiser for pediatric cancer. Students also felt that community groups such as GTECH Strategies were an important part of community improvement. In the brainstorming section, many students responded that a space with a recreation element, or simply somewhere to gather would be valuable to the local community.

Working with local architects and landscape designers, the design generated is a "gateway" garden, or beautified entryway to campus. Figure 3 shows the initial sketched design. 


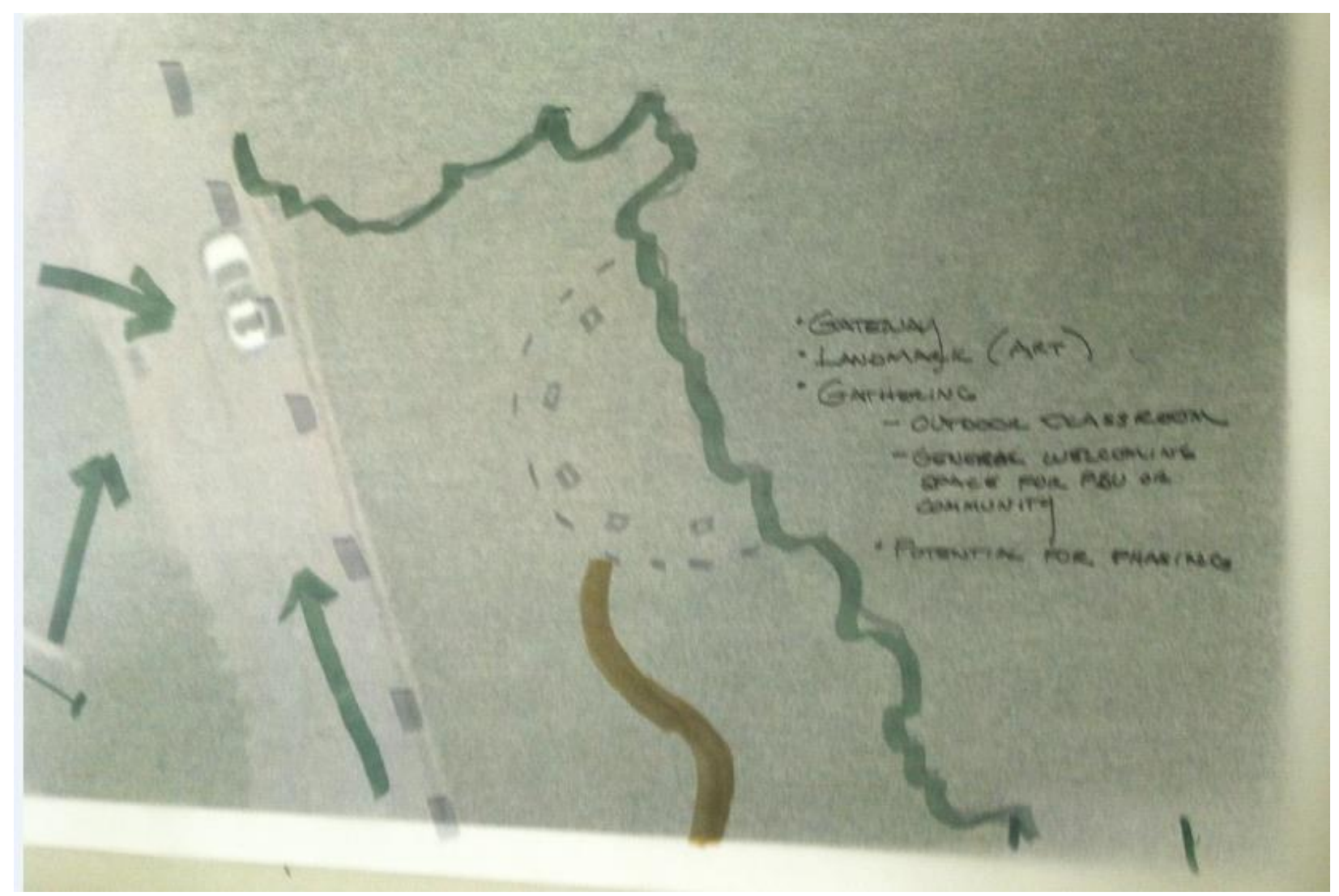

Figure 3: Initial design.

Feedback from students regarding the design resulted in several adjustments to the overall placement of design elements and orientation of the discussion space. Students felt that in order to best serve diverse audiences, a mixture of both formal space (i.e. grouped seating) as well as informal space (grassy area) would be more appropriate than the previously planned informal space. Students also felt continuing the 'doors' design element (shown in Figure 4) on the opposite side of the main installation would be a good way to showcase this design element. 


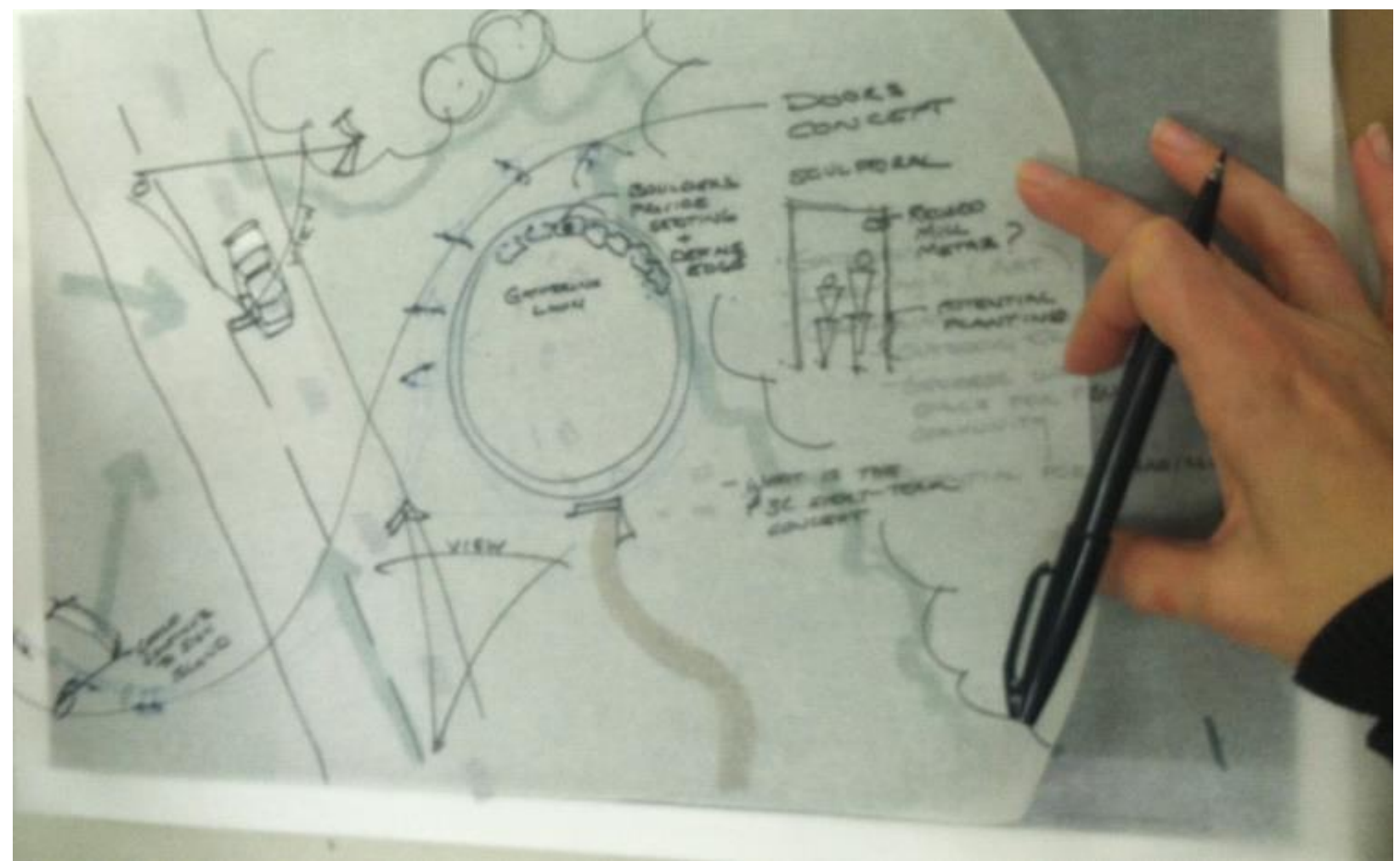

Figure 4: Design following student feedback.

Students were also surveyed following the design experience, although not before. Impacts measured were their understanding of the iterative nature of the design process, familiarity with the project, opinion about using the design process with this project as a learning tool, as well as confidence using the design process following the experience and enjoyment of the activity. Results from this survey are shown in Figure 5. 


\begin{tabular}{|c|c|c|c|c|c|c|c|}
\hline & 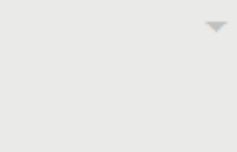 & $\begin{array}{l}\text { Strongly } \\
\text { Disagree }\end{array}$ & Disagree & $\begin{array}{l}\text { Neither } \\
\text { Disagree } \\
\text { Nor } \\
\text { Agree }\end{array}$ & Agree - & $\begin{array}{l}\text { Strongly } \\
\text { Agree }\end{array}$ & Total = \\
\hline$\checkmark$ & $\begin{array}{l}\text { I am familiar } \\
\text { with the } \\
\text { iterative } \\
\text { nature of } \\
\text { the } \\
\text { engineering } \\
\text { design } \\
\text { process. }\end{array}$ & $\begin{array}{r}0.00 \% \\
0\end{array}$ & $\begin{array}{r}0.00 \% \\
0\end{array}$ & $\begin{array}{r}0.00 \% \\
0\end{array}$ & $\begin{array}{r}46.67 \% \\
14\end{array}$ & $\begin{array}{r}53.33 \% \\
16\end{array}$ & 30 \\
\hline 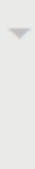 & $\begin{array}{l}\text { I am familiar } \\
\text { with } \\
\text { community } \\
\text { revitalization }\end{array}$ & $\begin{array}{r}0.00 \% \\
0\end{array}$ & $\begin{array}{r}0.00 \% \\
0\end{array}$ & $\begin{array}{r}3.33 \% \\
1\end{array}$ & $\begin{array}{r}\mathbf{4 0 . 0 0 \%} \\
12\end{array}$ & $\begin{array}{r}56.67 \% \\
17\end{array}$ & 30 \\
\hline 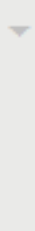 & $\begin{array}{l}\text { I thouaht the } \\
\text { GTECH project } \\
\text { was a good } \\
\text { wav to learn } \\
\text { engineering } \\
\text { design }\end{array}$ & $\begin{array}{r}0.00 \% \\
0\end{array}$ & $\begin{array}{r}0.00 \% \\
0\end{array}$ & $\begin{array}{r}6.67 \% \\
2\end{array}$ & $\begin{array}{r}23.33 \% \\
7\end{array}$ & $\begin{array}{r}70.00 \% \\
21\end{array}$ & 30 \\
\hline 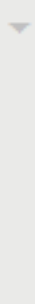 & $\begin{array}{l}\text { I feel } \\
\text { confident } \\
\text { about the } \\
\text { engineering } \\
\text { design } \\
\text { process to } \\
\text { evaluate } \\
\text { ideas. }\end{array}$ & $\begin{array}{r}0.00 \% \\
0\end{array}$ & $\begin{array}{r}0.00 \% \\
0\end{array}$ & $\begin{array}{r}3.33 \% \\
1\end{array}$ & $\begin{array}{r}\mathbf{4 3 . 3 3 \%} \\
13\end{array}$ & $\begin{array}{r}\mathbf{5 3 . 3 3 \%} \\
16\end{array}$ & 30 \\
\hline & $\begin{array}{l}\text { I enjoyed } \\
\text { this activity. }\end{array}$ & $\begin{array}{r}0.00 \% \\
0\end{array}$ & $\begin{array}{r}0.00 \% \\
0\end{array}$ & $\begin{array}{r}6.67 \% \\
2\end{array}$ & $\begin{array}{r}23.33 \% \\
7\end{array}$ & $\begin{array}{r}70.00 \% \\
21\end{array}$ & 30 \\
\hline
\end{tabular}

Figure 5: Example student feedback following the design experience.

Students rated the project highly as enhancing their understanding of the design process and indicated that they felt confident about using the design process to evaluate ideas following this activity. Responses to the survey also indicated that the design experience was beneficial to student learning as well as enjoyable. Please note that student participation in surveys is voluntary, therefore the n-values do vary.

As part of Goal \#1, students identified several elements of design that could be sourced locally to encourage sustainability. It is planned to use natural elements such as rock from foundations of demolished houses for seating as well as crushed stones from these for creation of a connecting path from the parking lot to the gateway space. Students also discussed using plantings such as herbs which can then be used in campus cuisine rather than decorative flowering plants as a design element to promote sustainability. The civic and community engagement students were active participants in this discussion, in line with Goal \#2. The community nonprofit was exceptionally pleased with the creativity of the students in sourcing materials for construction, as well as the idea of a kitchen garden. To expand the partnership, it was also suggested that both 
GTECH Strategies and the students hold workshops prior to planting and work sessions discussing elements of leadership. The students identified several topics for leadership including networking, public speaking, and management. The nonprofit was also excited about this element of the project and offered to provide materials and speaker support. Following these workshops, participants will also be surveyed and asked to reflect in order to identify shifts in attitude, design thinking and efficacy of training. Findings from all assessments and reflections will be compiled into a document detailing the impact of the GTECH Strategies project at its conclusion.

Continuing work:

This project is the launch pad for learning through service and interdisciplinary collaboration of engineering and other disciplines on our campus. It will provide a knowledge base useful to other educators and directions of future educational development. This project will also build community links for future projects while empowering underrepresented groups in both engineering and other disciplines. Initial take-aways from the project are that students felt more engaged with their community than through traditional learning, benefited from positive experiences with those outside their social sphere, and felt that the project enhanced their understanding of traditional classroom topics in an innovative manner. GTECH Strategies was also pleased with the initial outcomes of the project, citing student enthusiasm as a driving force for further community engagement initiatives. Additionally, GTECH Strategies felt that the project was a good fit for their goals of community improvement, engagement and collaboration. At the conclusion of the project all survey data and material from reflections will be compiled to determine the effectiveness of this project in reaching the expressed goals.

References:

1. 42 U.S.C.A. 12501 et seq. "National and Community Service Act of 1990"

2. Coyle, Edward J., Leah H. Jamieson, and William C. Oakes. 2005. EPICS: Engineering Projects in Community Service. International Journal of Engineering Education 21 (1): 139-50.

3. Dewey, John. Dewey on Education, edited by Martin Dworkin. New York: Teachers college Press, 1959.

4. Dym, Clive L., and Patrick Little. Engineering design: A project-based introduction. New York: Wiley, 2001.

5. Eyler, Janet \& Dwight E. Giles. Where's the Learning in Service-Learning? San Francisco, CA: JosseyBass, 2007.

6. Gass, Robert. "What is Transformation?" Social Transformation Project.

7. James, William. Talks to Teachers on Psychology: and to Students on Some of Life's Ideals (1899). New York: Dover Publications, 2001

8. Krain, M., and A. M. Nurse. 2004. Teaching human rights through service learning. Human Rights Quarterly 26 (1): 189-207. 
9. Lansverk, M. 2004. An apologie for service learning. The Montana Professor 14 (2).

10. May, G. S., \& Chubin, D. E. (2003). A retrospective on undergraduate engineering success for underrepresented minority students. Journal of Engineering Education, 92(1), 27-39.

11. Myers-Lipton, S. 1998. Effect of a comprehensive service-learning program on college students' civic responsibility. Teaching Sociology 26 (4): 243-58.

12. Piket-May, Linda and Avery, James (2001). Service Learning First Year Design Retention Results, ASEE/IEEE Frontiers in Education Conference.

October 10-13, 2001, Reno, NV.

13. Seymour, E. (1995). The loss of women from science, mathematics, and engineering undergraduate majors: An explanatory account. Science Education, 79(4), 437-473.

14. TeachEngineering.org. National Science Foundation, n.d. Web. 14 Jan. 2015 